\title{
WORD ORDER AND ACCENT PLACEMENT IN TOPICS, FOCI, AND MARKERS OF DISCOURSE CONTINUITY
}

\author{
TATIANA YANKO \\ Institute of Linguistics, Russian Academy of Sciences, Moscow
}

A B S T RAC T

This paper is aimed at analyzing topic, focus, and discourse continuity markers in their interaction. The main problem with expressing discourse continuity is that it is generally identical with the means used to mark the topic: there is no formal difference in either the corresponding pitch accents or the principles guiding the choice of words to carry them. Nevertheless, certain strategies of marking the topic, focus, and discourse incompleteness within a single clause where the topic, focus, and discourse incompleteness have distinct accent bearers and the applicable pitch accents are found in a variety of languages. The parameters of such strategies are discussed. These patterns are exemplified below by the Russian, German, and English data.

\section{[1] INTRODUCTION}

The point of departure for this article is that prosody and word order signal at least two different types of discourse meaning. The first type are the meanings that shape a sentence as a speech act with a certain illocutionary force. A sentence has to have a focus marked with a specific falling (focal) tone to be construed as a statement. In addition to the focus, a statement may include an optional topic which does not constitute a sentence as a speech act but it sets the conditions for performing a speech act. The second type of meaning signalled by prosody involves discourse continuity that constitutes the connected text.

The main problem with expressing discourse continuity, i.e. showing that the current step of narration is non-final, is that it is in most cases identical with the means marking the topic: there is no formal difference in either the corresponding pitch accents or the accent placement. A question then arises as to whether there are means of expressing discourse incompleteness different from the means of expressing the topic. I will demonstrate below certain patterns of marking the topic, focus, and discourse incompleteness independently within a single clause where the topic, focus, and discourse incompleteness have distinct accent bearers and the applicable pitch accents. 
My data are taken from the Russian oral speech corpus 'Night Dream Stories' - a subpart of the Prosodically Annotated Corpus of Spoken Russian (PrACS-Russ, cf. Spokencorpora (2014); for details see Kibrik \& Podlesskaja (2009)) and a minor working corpus of speech recordings particularly set up for this analysis. The software program Praat is used for analyzing sounding data.

\section{[2] RUSSIAN}

The Russian example in (1) demonstrates that the expression of topic and discourse incompleteness generally does not differ.

(1) EŠČË, u menja byl TAKOJ son, kak ja possorilsja s DRUZ'J a s drugom ne POSSORILSJA, PODRUZŽKA, eë kto-to ST $\underline{U K N U L, ~ i ~ o n a ~ p o p a l a ~}$ v BOL'NICU...

'I also had this dream where I quarrelled with my friends, with my girlfriend, but I did not quarrel with my friend, and then my girlfriend, somebody hit her and she was taken to the hospital'

The segments of example (1) -

(i) EŠČ

(ii) u menja byl TAKOJ son 'I had such a dream' with the accent bearer TAKOJ 'such'

(iii) kak ja possorilsja s DRUZ'JAMI 'as if I quarrelled with my friends' with the accent bearer DRUZ'JAMI 'with friends'

(iv) s PODRUŽ̌KOJ 'with my girlfriend'

(v) a s drugom ne POSSORILSJA 'but I did not quarrel with my friend' with the accent bearer POSSORILSJA 'quarrelled',

(vi) PODRUŽKKA 'the girlfriend'

(vii) eë kto-to STUKNUL 'somebody hit her' with the accent bearer STUKNUL 'hit'

(viii) i ona popala $\mathrm{v}$ BOL'NICU 'and she got into the hospital' with the accent bearer BOL'NICU 'hospital'

- have identical rises on the tonic syllables of the accent-bearing words followed by frequency falls on the post-tonics if any, cf. Figure 1. (The accent-bearing words are capitalized, the tonic vowels are underlined). The segments (i)-(viii), therefore, can be viewed as serial topics referring to the same focus located in the forthcoming context. At the same time, these segments can as well be construed as discourse constituents that drive the narration forward. 


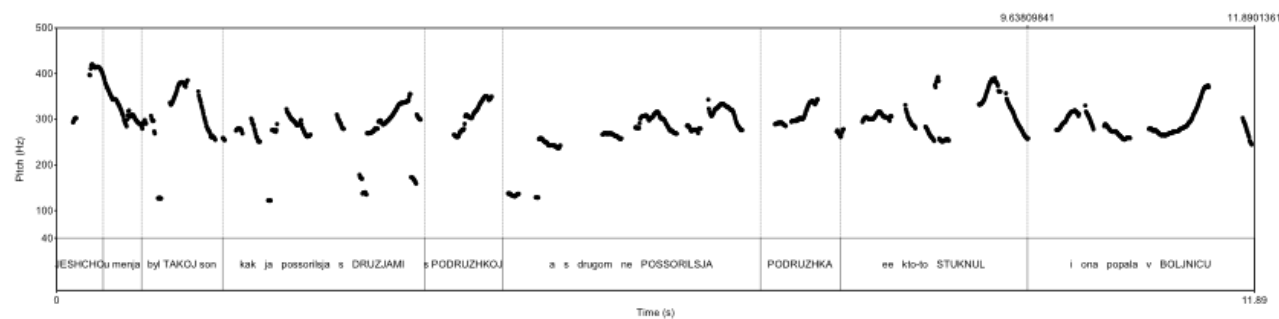

FIGURE 1: The frequency tracing of example (1).

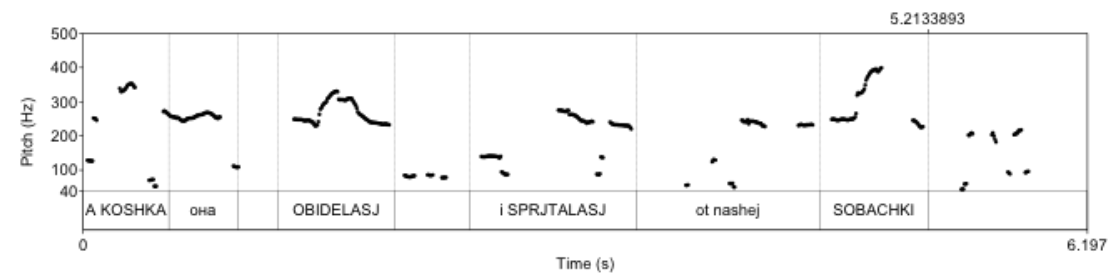

FIGURE 2: The frequency tracing of example (3).

One could use syntactic criteria to differentiate topics from discourse continuity because clauses are most likely to be discourse components while, e.g. noun phrases, are most likely to be the topics. For instance, in example (1) the segment (vii) eë kto-to ST $\underline{U}$ KNUL 'somebody hit her' is a discourse element, while (vi) PODRUŽKA 'girlfriend' is a real topic. Nevertheless, sentential elements can also play part of a topic. Thus, in sentence (2) the component Vadik poznakomilsja $s$ MARUSEJ 'Vadik met Marusja' has a structure of a complete clause, but nonetheless it serves as a topic referring to the focus $v$ KIEVE 'in Kiev' in the reply to the question Gde Vadik poznakomilsja s Marusej? 'Where did Vadik meet Marusja?'.

(2) Vadik poznakomilsja s MARÚSEJ v KIEEVE.

'Vadik met Marusja in Kiev.'

As a result, the whole sentence Vadik poznakomilsja s MARUSEJ serves as a topic. An additional reason for treating Vadik poznakomilsja s MARUSEJ as a topic is that the focal constituent $v$ KIEVE 'in Kiev' is an NP rather than a clause.

At the same time, there is a variety of independent ways in which the illocutionary force and discourse continuity can be designated. One such way is based on specific accent-placement. Consider example (3) below.

(3) A KoŠKA ona obịdelas' i SPRJATTALAS' ot našej SOBÁČKI... And the cat she got offended and hid from our doggy 
Here, the word SPRJATALAS' 'hid out' carries a focal fall and plays the part of the focus (exactly like in the hypothetic sentence (4)), while a rise on the sentencefinal word SOBAČKI 'doggy' (in (3)) is an autonomous marker of a discourse connection.

(4) Koška obidelas' i SPRJATTALAS'

'The cat got offended and hid out.'

For the prosodic strategy with a discourse continuity accent bearer placed sentencefinally and after the independent focal accent bearer, I suggest the term 'marking a discourse connection in the tail'. Ot našej SOBAČKI 'from our doggy' in sentence (3) is the tail. The notion of tail and example (5) I take from Vallduvi \& Engdahl (1996).

(5) You shouldn't have brought chocolates to the president. He HATES chocolates.

In (5) hates is the focus, while the second occurrence of the word chocolates is the tail. It is a fragment of a topic because it is borrowed from the first sentence, but it is placed sentence-finally because the basic word order in English is SVO. The tail chocolates is deaccented (i.e. it does not carry any relevant accent) as it should be when the topic is placed after the focus. However, in sentence (3) the tail ot našej SOBAČKI is used for marking discourse continuity.

Consider the frequency tracings of example (6) from A. Chekhov as read out by two actors:

(6) MALO ja smyslju v mužskoj krasote Little I understand in men's beauty

Both readings have a focal fall on the accent bearer of the focus, the word MALO 'little, few'. Ja smyslju $v$ mužskoj krasote is the tail. Here, the initial position of the focal accent bearer is accounted for by the lexical focalizing effect of the meaning 'little, few'; about the focalizing effect of MALO 'little, few' cf. Bulygina \& Aleksej Šmelev $(1997,200)$. The first reader leaves the tail deaccented (the upper graph of Figure 3), while the second reader uses the tail to articulate a rise on the word KRASOTE 'beauty' which designates discourse continuity (the lower graph of Figure 3).

The notion of tail is not new, it is traditionally used in phonetics in tone groups analysis where it designates the atonic syllables of a tone group: '...any syllable or syllables following the nucleus (or the stressed syllable) in the same tone group' (Palmer 1924,10). The difference between the term 'tail' within various approaches to spoken speech analysis consists in the fact that the phoneticians used the term to describe the tone groups arranged around the tonic syllable, while in Vallduvi 

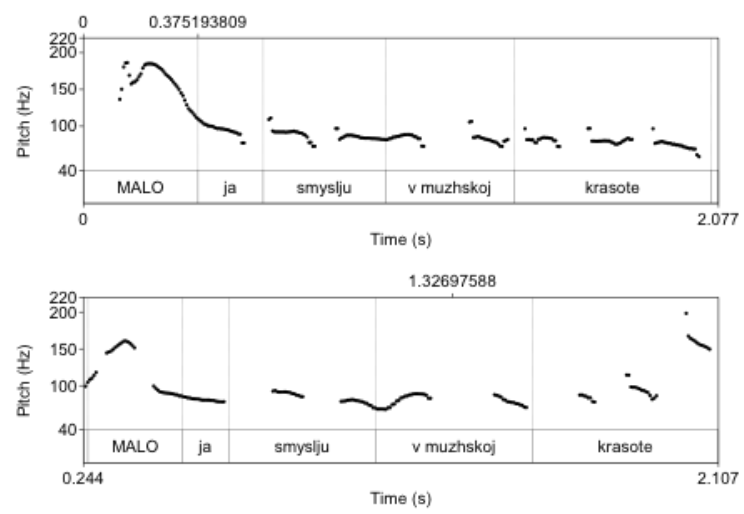

FIGURE 3: The comparative frequency tracing of example (6) readings.

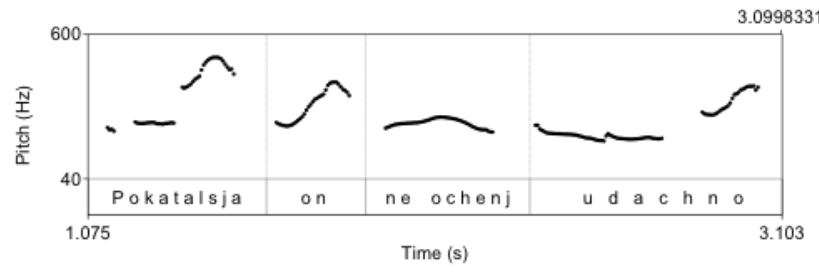

FIGURE 4: The frequency tracing of example (7).

\& Engdahl (1996) this notion is employed to describe the details of the topic-focus structure. Within the topic-focus theory a tail can designate both 1) a deaccented topic placed after the focus and 2) a component of a more than one-word focus minus its accent bearer if this accent bearer is positioned non-sentence-finally. For instance, in sentence (5), the word chocolates is the posttonic topic, while in (6) the tail ja smyslju v mužskoj krasote is a fragment of the focus. Moreover, within the topic-focus theory a tail can either remain atonic as in (5) and (6) (upper graph) or serve as the bearer of discourse continuity as in (6) (lower graph).

Sentence (7) is another example of discourse continuity designated by the rise on the tail. This example carries the maximum number of communicative meanings expressed within the limits of one simple sentence.

$$
\begin{aligned}
& \text { POKATALSJA ON ne OČEN' UDAČNNO... } \\
& \text { skied he not very successfully } \\
& \text { 'His skiing was not very successful' }
\end{aligned}
$$

The two topics, focus, and discourse continuity all have autonomous markers here. The verb POKATALSJA 'skied' (which carries a prominent rise on the stressed syllable) is the initial topic, the pronoun $O N$ 'he' is the second topic, the adverbial $N E$ 


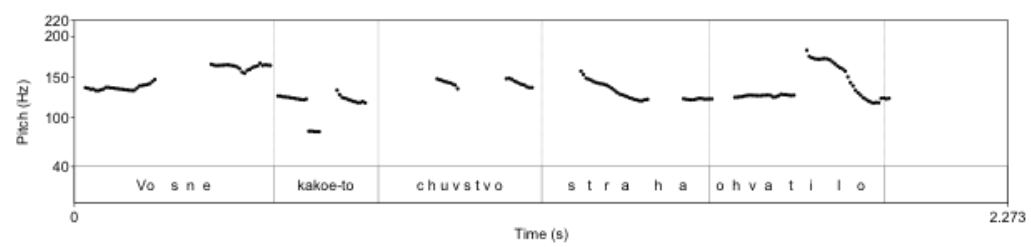

FIGURE 5: The frequency tracing of example (8).

OČEN' 'not very' is the focus. It carries a specific pitch accent of an emphatic ${ }^{1}$ focus. The sentence-final UDAČNO 'sucessfully' is placed postpositionally with respect to the focus. It functions, therefore, as a tail here as it carries a 'scooped' (late rise) accent of incompleteness. Emphasis determines that the accent bearer occupies a non-sentence final position. Consequently, the word UDAČNO 'sucessfully' plays the part of the accent bearer of discourse continuity.

A specific Russian strategy of marking the topic and the focus independently from discourse continuity is exemplified by sentence (8).

(8) Vo SNE kakoe-to čuvstvo STRAXA OXVATILO...

in dream some sensation of fear grasped

'When dreaming, some sensation of fear grasped me'

Here, the word STRAXA 'of fear' is the accent bearer of the focus, it carries a slight fall of frequency on the tonic syllable stra-, while the sentence-final verb OXVATILO 'grasped' is the accent bearer of discourse continuity, it has a rise on the tonic syllable -ti-. Here, the finite verb OXVATILO does not occupy its basic position between the subject and the object: in sentence (8) the verb moves to the sentence final-position.

Sentence (9) exemplifies the same strategy of marking discourse continuity.

(9) Ja iz KOMNATY VYXOŽU...

I from room go.out

'I am leaving the room...'

[1] Emphasis is a type of communicative meaning and its basic property is the ability to combine with other communicative meanings. As a result, emphatic topics, emphatic foci, and emphatic questions arise. Therefore, emphasis does not function in a sentence independently from the topic or the focus. The semantics of emphasis is to express the speaker's attitude with respect to unusual phenomena of life. In the statement I already have a son!, the speaker, first, is informing the hearer that $\mathrm{s} /$ he has a son, and, second, expresses the idea that $\mathrm{s} / \mathrm{he}$ is too young to have a son and that $\mathrm{s} / \mathrm{he}$ is proud of it. For details, see Yanko (2012a). 


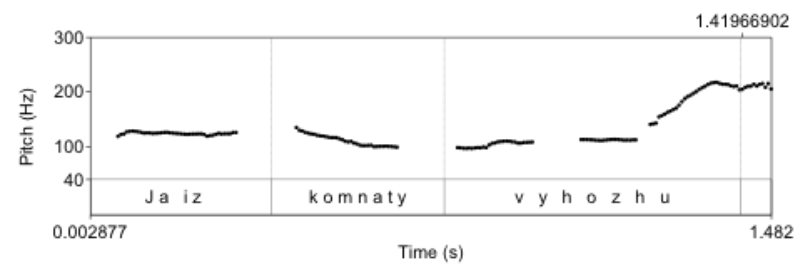

FIGURE 6: The frequency tracing of example (9).

Figure 6 demonstrates a fall on the accent bearer of the focus, the word KOMNATY 'room', and a rise on the sentence-final verb VYXOŽU 'go out', the accent bearer of discourse continuity. The basic word order (SVO) for this sentence is represented by sentence (8.1):

(10) Ja vyxožu iz KOMNATY

I went out from room

'I am leaving the room...'

The word order in (8) and (9) can only be construed as a result of a word order transformation because a verb which has arguments generally is not placed sentence-finally even in Russian (with its unlimited scrambling).

A question arises then as to what principles control the alignment of the phrase accent with the text: which words are the accent bearers of the focus, the topic, and the tails? The choice of an accent bearer is not random. The accent placement is conditioned by certain principles, where the cardinal parameter is the syntactic structure of a communicative constituent - the topic, the focus, the tail. For further discussion see Yanko (2001, 68-84) and Yanko (2011).

Example (11) shows that the accent bearer of discourse continuity is not obligatorily sentence-final:

$$
\begin{aligned}
& \text { Nas vsex razognali, skazali: NEL'ZJA GRIBY rvat'... } \\
& \text { us all drove away told forbidden mushrooms to pick } \\
& \text { 'They drove us away, they told us: it is forbidden to pick mushrooms' }
\end{aligned}
$$

In example (11) NEL'ZJ $\underline{A}$ 'forbidden' is the accent bearer of the focus, GRIBY rvat' 'mushrooms to pick' is the tail (the fragment of the focus) which holds the accent bearer of discourse connection GRIBY 'mushrooms', while rvat' 'to pick' is an atonic tail, because - according to the principles of the accent placement presented in Yanko $(2001,68-84)$ and Yanko (2012b) - the accent bearer of the infinitive phrases both GRIBY rvat' 'mushrooms to pick' and rvat' GRIBY 'to pick mushrooms' is the word GRIBY regardless of its position in the sentence. The word rvat' 'to pick' in (11) is, therefore, a 'the second-order tail'. 
The preliminary results of our analysis indicate that the tail function may be determined by the following factors:

- the non-final position of the focus accent bearer while its arguments, whose basic position is sentence-final, refer to given information (as in He HATES chocolates);

- the presence of lexical focalizers, like few, little, never, forever, rarely (as in I understand LITTLE about men's beauty);

- emphasis, or contrast ${ }^{2}$ (as in He skied VERY successfully);

- a specific transformation (only in Russian) which leads to the sentence-final position of the finite verb whereas its complements precede the verb (as in Ja iz KOMNATY VYXOŽU... 'I am leaving the room', literally 'I the room left...').

To compare the results of the Russian data analysis to the techniques functioning in the strict word order languages English and German, I demonstrate below that most sources of forming the tails are also accessible in English and German except for the sentence-final position of the verb (i.e. SOV or OSV).

The Russian language developed a specific strategy of moving the verb to the right edge of a sentence. Why specifically the verb? The reason for this could be as follows. When a finite verb has at least two arguments these arguments in all likelihood play the roles of the topic and the focus of the sentence. The argument referring to given information is the topic, whereas the argument referring to new information occupies the position of the focal accent bearer. This is a standard and statistically highly frequent situation. In such contexts the verb itself does not carry any relevant accents: it serves as a transition (in the terms of Firbas $(1965,1974))$ between the topic and the focus. Therefore, the verb is statistically the most independent component of a clause with respect to any sentential accents. Therefore, the finite verb can be used as the accent bearer of discourse continuity: the verb is postposed, assumes the function of the tail, and gets marked with the discourse continuity accent, cf. examples (8) and (9).

\section{[3] GERMAN}

In the strict word order languages, the postposition of a finite verb in the context of at least two arguments is impossible.

[2] Contrast is a type of communicative meaning and, like emphasis, it combines with other communicative meanings. As a result, contrastive topics, foci, and contrastive components of questions arise. Contrast presupposes the existence of a set associated with a contrasted item and a choice made within this set, and a reference to the current utterance to another utterance or opinion with which the speaker either agrees, or, on the contrary, disagrees. 


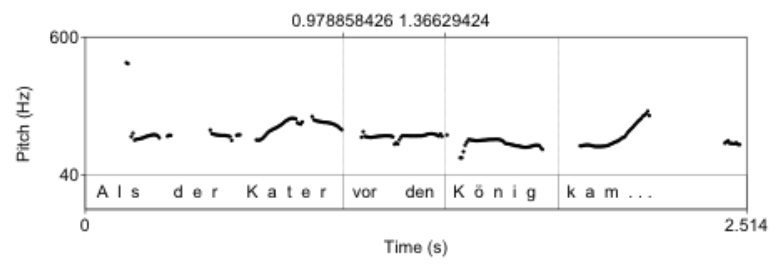

FIGURE 7: The frequency tracing of example (12).

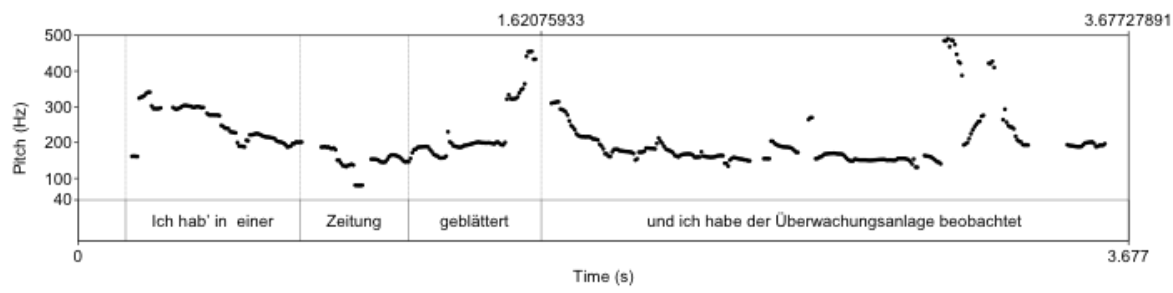

FIGURE 8: The frequency tracing of example (13).

Although verbs as accent bearers of discourse continuity are present in German, the origin of such a word order is not motivated by the transformations of the basic word order as in Russian.

In German the verb sentence-final position is accounted for by the fixed position of the finite verb in a German dependent clause as in (12) and V2 word order in a matrix clause as in (13). In (13), the V2 position is occupied by a finite auxiliary verb, while the lexical nonfinite verb form is located sentence-finally. So, as far as the German dependent clauses are concerned the resemblance to the Russian verb-final sentences is quite distant. Examples (12) and (13) are borrowed from Pal'ko (2010).

(12) Als der Kater vor den KÖNIG KAM...

When the cat to the king came...

Figure 7 shows a low level tone on the focus accent bearer, the word König, and a substantial rise on the continuity marker, the finite verb KAM.

(13) Ich hab' in einer ZEITUNG GEBLÄTTERT...

I have in a newspaper looked

In sentence (13), the tonic syllable of the word ZEITUNG 'newspaper' carries a focal fall, while the late rise on the participle GEBLÄTTERT 'looked through' is the accent bearer of discourse continuity. 


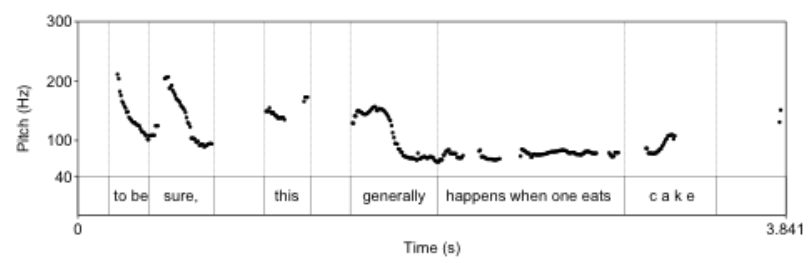

FIGURE 9: The frequency tracing of example (14).

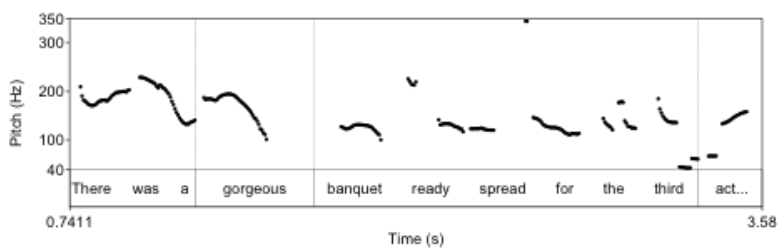

FIGURE 10: The frequency tracing of example (15).

Thus, the German and the Russian sentence-final verb forms as discourse continuity markers have different sources.

\section{[4] ENGLISH}

Consider the following examples of a strategy by which discourse continuity is signalled in English as distinct from the manner in which topics are marked.

Example (14) is taken from an artistic reading of Alice in Wonderland. ...to be SURE, this GENERALLY happens when one eats CAKE...

The topic to be sure is designated as a topic by a rise of frequency on the tonic syllable of the accent bearer of the topic, the word SURE. A focal fall is placed on the accent bearer of the focus, the word GENERALLY. The sentence-final word CAKE demonstrates a rise of discourse continuity. The fragment happens when one eats cake is the tail here because it is located after the accent bearer of the focus. The quantification word GENERALLY is a focally polarized lexical unit; on the association of universal quantification with the topic cf. Partee (1999).

In sentence (15) from Dickens's Nicolas Nickleby, the tail is signalled by emphasis in combination with the focus.

(15) There was a GORGEOUS banquet ready spread for the third ACT...

The frequency tracing demonstrates the emphatic focus GORGEOUS, whose lexical 


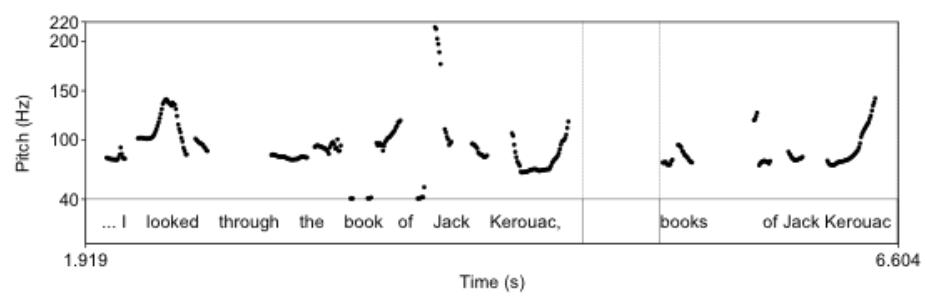

FIGURE 11: The frequency tracing of example (16).

meaning agrees with the prosody of emphasis. The rest of the clause is, therefore, a tail which paves the way for the sentence-final word ACT to appear as the accent bearer of discourse continuity.

Example (16) is taken from a radio interview.

(16) I looked through the book of Jack Kerouac, BOOKS of Jack KEROUAC...

The contrast in sentence (16) is accounted for by the speaker's self-correction: the speaker specifies that he meant not one of Jack Kerouac's books but several: the word BOOKS in plural has a contrastive focus here. The second occurrence of the post-tonic attribute of Jack Kerouac is the tail, the late rise on the word KEROUAC designates discourse continuity.

\section{[5] CONCLUSION}

The autonomous marking of the topic, focus, and discourse continuity is based on employing a segment placed after the focal accent bearer of the clause. This segment is termed the tail of a clause.

A tail either remains deaccented or carries a prosodic cue for discourse continuity.

Tails are determined by a variety of factors such as lexical focusing, contrast, emphasis, and word order transformations. These factors create conditions for the non-final placement of the accented focal word so that it paves the way for forming a tail. For instance, when the finite verb of a sentence is located sentencefinally, after its complement, functioning as the focal accent bearer, the verb itself becomes the accent bearer of discourse continuity. This pattern is typical for the Russian colloquial speech. English and German do not allow such sequences. Thus, though Russian, English, and German have comparable means for expressing discourse continuity independently from the way in which the topic and the focus are expressed, the sources of such means may be different. 


\section{ACKNOWLEDGEMENTS}

This study has been granted the financial support of the Russian Foundation of Fundamental Reaserch (project N 16-06-00226).

\section{REFERENCES}

Bulygina, Tat'jana \& Aleksej Šmelev. 1997. Jazykovaja konceptualizacija mira (na materiale russkoj grammatiki). Moskva: Jazyki russkoj kul'tury.

Firbas, Jan. 1965. A note on transition proper in functional sentence analysis. Philologica pragensia 8(2-3). 170-176.

Firbas, Jan. 1974. Some aspects of the czechoslovak approach to problems of functional sentence perspective. In František Daneš (ed.), Papers on functional sentence perspective, 11-37. Prague: Academia.

Kibrik, Andrej \& Vera Podlesskaja (eds.). 2009. Rasskazy o snovidenijakh: Korpusnoe issledovanie ustnogo russkogo diskursa. Moskva: Jazyki slavjanskikh kul'tur.

Pal'ko, Marina. 2010. Intonacionnye sredstva vyraženija kommunikativnykh značenij (na materiale nemeckogo i russkogo jazykov). Avtoref. diss. kand. filol. n. Moskva.

Palmer, Harold Edward. 1924. English intonation with systematic exercises. Cambridge: Heffer and Sons.

Partee, Barbara. 1999. Focus, quantification, and semantics-pragmatics issues. In Peter Bosch \& Rob van der Sandt (eds.), Focus: Linguistic, cognitive, and computational perspectives, 213-231. Cambridge: Cambridge University Press.

Spokencorpora. 2014. Prosodically annotated corpus of spoken Russian. Pilot version. http://spokencorpora.ru.

Vallduvi, Enric \& Elisabet Engdahl. 1996. The linguistic realization of information packaging. Linguistics 34. 459-519.

Yanko, Tatiana. 2001. Kommunikativnye strategii russkoj reči. Moskva: Jazyki slavjanskikh kul'tur.

Yanko, Tatiana. 2011. Accent placement principles in Russian. Komp'juternaja lingvistika i intellektual'nye tekhnologii 10. 712-726.

Yanko, Tatiana. 2012a. Extracting subjective information from spoken discourse: The case for prosodic emphasis. Komp'juternaja lingvistika i intellektual'nye tekhnologii 11. 664-673. 
Yanko, Tatiana. 2012b. Razmeščenie akcentnykh pikov v predloženii kak vyraženie «smyslov govorjaščego». In Marija Voejkova (ed.), Ot značenija $k$ forme, ot formy k značeniju, 631-646. Moskva: Jazyki slavjanskikh kul'tur.

AUTHOR CONTACT INFORMATION

Tatiana Yanko

Institute of Linguistics, Russian Academy of Sciences, Moscow

tanya_yanko@list.ru 